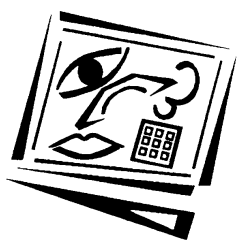

\title{
A metacognitive approach to enhancing Chinese language speaking skills with audioblogs
}

\author{
Yuh Huann Tan \\ Ministry of Education, Singapore \\ Seng-Chee Tan \\ Nanyang Technological University
}

\begin{abstract}
Situated in the field of computer assisted language learning (CALL), this article reports an instrumental case study on the use of audioblogs for developing students' Chinese speaking skills. The intervention focused on scaffolding students in metacognitive reflection of their oral performances. The case focused on seven students who completed substantial part of the activities, and the main sources of data came from the oral recordings and interactions in their audioblogs. A significant improvement in the mean scores of pre- to post-test oral performance was found, which indicated the benefits of this approach. The students were found to adopt a systematic approach in their reflection: evaluating --> monitoring --> planning, with greater amount of attention devoted to the monitoring strategy. However, a disproportionate distribution of metacognitive knowledge usage was found in students' self-assessment. Task knowledge was the predominant metacognitive knowledge used by students, whereas person knowledge and strategy knowledge were neglected by the students. Teachers who are keen to implement a similar instructional approach could develop strategies to focus the students' attention on the latter two types of metacognitive knowledge.
\end{abstract}

\section{Introduction}

The advent of Web 2.0 technologies brought great excitement among computer users. While Web 1.0 provided a platform to access and retrieve information from the Internet, Web 2.0 introduced a new dimension of ownership to the users in a highly participatory environment. One popular Web 2.0 technology is weblog, or blog. With blogs, the web users are empowered to participate as a writer rather than as a mere reader, as an active contributor rather than a passive receiver of information (Gounari, 2009). More importantly, blogging gives voices to the masses, which otherwise have been a privilege enjoyed by a few elite writers. Since the inception of blogs about a decade ago, blogs have been created at a phenomenal rate. In 2008, the Blog Herald (http:/ / www.blogherald.com/) reported the existence of over 60 million blogs and the number more than tripled to 185 million three years later (Helmond, 2008).

As in the case of other technologies, educators worldwide have been leveraging the affordances of blogs for teaching and learning (e.g., Ladyshewsky \& Gardner, 2008; Tekinarslan, 2008). Some common applications include the use of blogs by students to publish their writings, to review each other's work, and to build personal portfolios. Within a short time, multimedia content became important, creating new variants of 
blogs like podcasting or audioblogs, and vlogs (video blogs), which generated new affordances for educational purposes. Educational research, however, is yet to catch up with this rate of technological development and there is a need for empirical studies on the impact of blogs. In this paper, we studied the applications of audioblogs (blogging with audio posts) as the mediating information and communication technology (ICT) tool for the teaching and learning of Chinese language speaking at secondary school level. We focused particularly on scaffolding students in their metacognition to build their competencies in self-evaluation of their oral performances and planning for their future speaking tasks.

\section{Literature review}

This study is situated in the field of computer-assisted language learning (CALL), in particular, the use of audioblogs for developing students' Chinese speaking skills. We focus on scaffolding students in metacognitive reflection of their oral performances. The following review provides the background to this study and its intended contributions in this field of study.

\section{Blogs as a computer-assisted language learning tool}

Research on computer-assisted language learning (CALL) has a history that can be traced to the 1960s. The use of CALL is closely related to the prevalent language teaching approaches. In the 1960s when a behaviourist paradigm of learning prevailed, CALL was used mainly to support drill and practice approaches; in recent years when social constructivist paradigms of learning gained acceptance, integrative CALL supported by multimodal representations (e.g. graphics, sounds, animations) is being used increasingly to support students' meaning making through social interaction (Kern \& Warschauer, 2000). Recent CALL studies include the studies of communication tools such as email (e.g., Young, 2003), discussion forum (e.g., Yildiz \& Barbara, 2003), Internet Relay Chat (e.g., Paolillo, 2001), computer conferencing systems (e.g., Rosell-Aguilar, 2005), and instant messaging (e.g. Segerstad \& Ljungstrand, 2002) in support of the communicative approach for language teaching. These interaction tools are also classified as computer-mediated communication (CMC) tools and are often used to promote reading and writing; research on speaking skills development is relatively scarce. Attempts were made to combine CMC applications with face to face interactions to develop speaking skills (e.g., Volle, 2005; Wang, 2004). The advent of blogs enhances the potential for the use of CMC tools in language learning.

The history of blogging can be traced to the use of the web for personal daily entries ('logs') by Jorn Barger in 1997. One of the most predominant applications among bloggers is to recollect, reflect and write on one's past experience. Educators have since adopted the use of blogs in at least four ways (Ray, 2006):

1. For fast and efficient communication of administrative information between teachers, students and parents;

2. For hosting of educational resources and lesson information pertaining to a course, and to exchange comments within the blogs;

3. For students to learn and teachers to work collaboratively through maintaining a blog as a group; and

4. For showcasing students' work. 
In an audioblog, the blogger can also speak and record his or her voice as the mode of expression, in lieu of writing; it thus allows a student to reflect and express themselves through oral recordings ( $\mathrm{Hsu}$, Wang \& Comac, 2008). By visiting each other's blogs and listening to the posts containing audio recordings, students can exchange comments on each other's ideas and oral performances. The comment function thus allows students to engage in collaborative learning and meaning making. Over time, as the number of posts accumulates, the archived posts and comments left by teachers and peers enable students to reflect and internalise their knowledge (Bartlett-Bragg, 2003).

Given the relatively short history of blogging technology, research on the use of blogging for language learning has gained momentum only recently. Through a survey with 1298 Primary Four (Grade 4) students in Hong Kong, Tse, Yuen, Loh, Lam and $\mathrm{Ng}$ (2010) found that $60 \%$ of the students had not read any Chinese blogs and $80 \%$ had not read any English blogs. The students' reading proficiency was significantly correlated with their consultation of blogs and the choice of blogs was dependent on social distance, that is, their familiarity with the owners or persons related to the blogs. Lou, Wu, Shih and Tseng (2010) found that the use of blogs enhanced high school students' performance in Chinese language composition; the students also indicated positive attitudes towards the use of blogs and composition writing. Sun (2010) found that extensive writing using blogs helped undergraduate students who studied English as a foreign language to improve their writing skills; the process also improved their motivation to write and helped to develop self-monitoring strategies. Shih (2010) found that a blended learning approach with video-based blogs was effective in helping university seniors improve their public speaking skills. Among the 44 participants, $82 \%$ of them improved in professional public speaking skills in aspects such as enunciation, articulation, facial expressions, posture, and gestures. Research on educational applications of audioblogs remains scarce. For example, Hsu, Wang, and Comac (2008) reported positive user experience in using audioblogs for learning of English language. Davis \& McGrail (2009) described how a teacher provided feedback to fifth-grade bloggers using podcasting, which helped the students to improve their proof-revising skills and influenced them to provide feedback to their peers using podcasting.

The paucity of studies on audioblogs leaves us little clues about the pedagogical applications of audioblogs for teaching and learning of speaking skills. Given the affordance of blogs as a reflective tool, we identified metacognition as one aspect of intervention that we can focus on.

\section{Metacognition and speaking}

Metacognition is the "knowledge and cognition about cognitive phenomena" (Flavell, 1979, p.906), otherwise known as thinking about thinking (Livingston, 1997). Metacognition involves monitoring one's cognitive processes, and regulating these processes after one gains an understanding of them (Leahey \& Harris, 1997). In her discussion on methods to develop autonomous language learners, Wenden (1998) adopted Flavell's (1979) categorisation of metacognitive knowledge, namely: person knowledge, task knowledge, and strategic knowledge. Wenden (1998) regarded person knowledge as a learner's general understanding of how learning takes place and how factors such as age, aptitude, motivation, cognitive and learning style can affect language learning. Task knowledge referred to the understanding of procedures that are required to ensure successful completion of a language task. Task knowledge may 
include the purpose, the nature, the difficulty level and the demands of a language task. Strategic knowledge includes (1) knowing the effective strategies that will lead to completion of specific language tasks, and (2) general knowledge about language learning that serves as a guide to the choice of strategies. With these three types of metacognitive knowledge, language learners are able to engage in self-appraisal (Paris \& Winograd, 1990) to monitor their language task performance.

Where speaking is concerned, there appears to be few empirical studies that link metacognitive knowledge to the learning of speaking. Zhang and Goh (2006) studied the relationship between students' metacognitive awareness of speaking and strategy knowledge; Nakatani (2005) investigated the relationship between metacognitive awareness-raising training and oral communication strategy use; Kaderavek, Gillam, Ukrainetz, Justice and Eisenberg (2004) explored the relationship between narrative production and children's self-assessment of their oral performances. Among the limited research studies, the findings were generally positive in that learners benefited and improved their oral skills when metacognitive strategies were introduced in the training (Nakatani, 2005). As existing research tends to focus on cognitive strategy applications and languages of the Western world, this study attempts to study the effect of incorporating metacognitive strategies for the learning of Chinese language.

The above review helps to identify several research gaps, in particular, the sporadic attempts to teach speaking skills with CMC tools, the scarcity of empirical research on the educational applications of audioblogs to facilitate learning of Chinese speaking skills, and the lack of study on the roles of metacognition in learning of speaking skills. This study could contribute to these areas of research. In addition, the findings could provide practical information for teachers who are interested in the use of audioblogs for enhancing students' speaking skills.

\section{Research questions}

The research questions guiding this study are:

1. Does the use of audioblogging followed by peer critique and self-assessment lead to an improvement in Chinese language speaking skills?

2. What kinds of metacognitive behaviours are exhibited in the self-assessment of students' speaking tasks?

\section{Methods}

This study adopts an instrumental case study methodology (Stake, 2005), which is an appropriate approach to gain a deeper understanding of an event, in this case, the use of audioblogging for teaching and learning of Chinese speaking skills. This is also an interventional study that intentionally introduces the use of audioblogs to the students and develops metacognitive skills among them. This research took place in a Singaporean government school (Grade 7-10), where students learnt two languages in school, namely English and the mother-tongue language under the nation's bilingual policy. The case focused on seven students who completed all the activities, and the main sources of data came from the oral recordings and interactions in their audioblogs. 


\section{Participants}

The participants in our studies were all Secondary 2 (Grade 8) students, aged 13-14, of Chinese ethnicity and all studied Chinese language as their mother-tongue language. From the total population of 158 Secondary Two students in the school, 25 students volunteered to participate in the study as an enrichment activity outside the curriculum hours.

The 25 participants were initially assigned randomly into groups of five. Four weeks into the study, the students were re-assigned into groups of three (with an exception of one group of four) to provide more opportunities for students to interact with each other. As an instrumental case study that focused on understanding the phenomenon that is being studied, it is critical for the students to follow the cycle of activities so that the treatment effect can be accounted for. Because the participation was voluntary, only seven students followed through the prescribed activities and completed at least four out of seven cycles of speaking activities in the eight weeks. Our analysis focused on the oral performance and the posts from these seven students.

\section{Intervention}

The implementation of this study occurred from July 2006 to September 2006 and lasted for eight weeks. Eight one-hour lessons were conducted weekly after curriculum time. The very first lesson had two objectives: (1) to introduce to the students about the learning activities and (2) to familiarise students with the operations of the audioblog platform. Each student was provided with a portable MP3 player and recorder and a personal audioblog account through which they could upload their recorded oral performances. The MP3 technology refers to MPEG-1 Audio Layer 3, which is a popular audio encoding format. MPEG-1 defines a group of Audio and Video (AV) coding and compression standards agreed upon by the Moving Picture Experts Group (MPEG).

The students carried out a weekly cycle of activities as follows:

1. Record an oral performance on a given topic using the MP3 recorder-player provided to them

2. Listen and comment on peers' oral performances

3. Read comments provided by peers

4. Conduct a self-assessment of oral performance

5. Carry out a second recording based on the same topic as in (1)

Table 1: Topics given to students for oral performance (translated to English)

\begin{tabular}{|l|l|}
\hline \multicolumn{1}{|c|}{ Week } & \multicolumn{1}{c|}{ Topic title } \\
\hline 0 (Pre-test) & Teenagers buying branded goods \\
\hline 1 & Bullying in school \\
\hline 2 & Pressure faced by teenagers \\
\hline 3 & Teacher-student relationship \\
\hline 4 and 5 & Do Singaporeans display courtesy? \\
\hline 6 & Which is more important, appearance or inner beauty? \\
\hline 7 & Teenagers running away from home \\
\hline 8 & Youth's addiction to online gaming \\
\hline 9 (Post-test) & Teenagers engaging in a boy-girl relationship \\
\hline $\begin{array}{l}\text { Note: Italicised words are used as a short-form to refer to the topic title in } \\
\text { subsequent sections. }\end{array}$ \\
\hline
\end{tabular}


For the pre- and post-tests, no peer and self-assessment were conducted. The topics given to the students (see Table 1) were modelled after topics that appeared in the General Certificate of Education (GCE) O-Level Chinese Language examinations. These topics focused on social issues that most teenagers faced. For each topic, the students were provided with newspaper reports or documentary programs to gain some background knowledge of the issues concerned.

To build up students' capacity in metacognition, the following scaffolding strategies were used: (1) Assessment criteria for oral performance were provided (Table 2); (2) Sentence opening cues were provided for students to provide feedback to their peers (Table 3); and (3) sentence opening cues were provided for students to assess their own performance (Table 4). Note that all the information provided to the students was in Chinese; Tables 2, 3, and 4 reported in this paper are the English translations.

The assessment criteria presented in Table 2 were adapted from the assessment rubrics used in the GCE O-level Chinese Language examinations, which elaborated on the key areas that are expected of a student's oral speaking in an oral examination.

Table 2: Assessment criteria for students to listen to oral performance and to provide comments (English translation)

\begin{tabular}{|c|c|}
\hline $\begin{array}{l}\text { Assessment } \\
\text { criteria }\end{array}$ & Elaborations \\
\hline Content & $\begin{array}{l}\text { - } \text { Breadth - discuss an issue from different perspectives } \\
\text { - } \text { Elaboration/Depth - discuss the topics with more than one idea } \\
\text { - } \text { Originality - provide one's own point of view } \\
\text { - Organisation- discuss ideas in a logical manner }\end{array}$ \\
\hline Expression & $\begin{array}{l}\text { - Fluency - speak with few pauses or repeated words; demonstrate confidence } \\
\text { - Vocabulary - appropriate use of difficult terms or idioms } \\
\text { - Pronunciation - pronounce the words correctly } \\
\text { - Intonation - speak with relevant tone and pitch }\end{array}$ \\
\hline
\end{tabular}

A list of sentence openings designed based on Bloom's taxonomy (1956) in the form of a printed handout was provided as scaffolds for the students to think more critically when commenting upon their peers' recordings (see Table 3). Bloom's taxonomy was chosen as the students had learnt about the different types of thinking skills in their school curriculum.

After the students had exchanged comments, they were required to perform a selfassessment of their oral performances. A list of sentence openings designed on the basis of the metacognitive framework proposed by Goh and Zhang (2001) was provided in the form of a printed handout (see Table 4). The students were asked to reflect on the four areas listed in the table. They were not specifically told that metacognition was involved in the reflection process they were going through. After the reflection, students were required to immediately perform an oral recording on the same topic and upload it to their audioblogs.

After the above weekly cycle of activities that the students were tasked to conduct in their own time, the teacher would check whether the students had carried out their assigned learning activities in the follow up, face to face session. During this session, good examples of students' reflections were highlighted to encourage students to learn from their peers on how ideas can be represented in their self assessment. This was followed by the introduction of a new topic for their next speaking task. During weeks 
4 and 5, there were school-wide common tests. As the students had to spend more time to prepare for their tests, the activity was extended to two weeks. In the ninth week, a post-test was administered using the same procedure as the pre-test except that students were required to speak on a new topic. The same test was not reused to reduce the confounding testing effect that could lead to better performance (Bygate, 2001). The pre-test and post-test topics were of similar level of difficulty as judged by three experienced Chinese language teachers.

Table 3: Scaffolds for students to provide critical comments (English translation)

\begin{tabular}{|c|c|c|}
\hline $\begin{array}{l}\text { Types of } \\
\text { comment }\end{array}$ & Sentence openings & $\begin{array}{l}\text { Bloom's } \\
\text { taxonomy }\end{array}$ \\
\hline Comparison & $\begin{array}{l}\text { 1. A's oral performance is better than B's recording because (for } \\
\text { example) } \\
\text { - A listed three reasons and B gave only one. } \\
\text { - A suggested two solutions to the problem and B gave only one. } \\
\text { 2. Compared with A, B's opinion is less encompassing. } \\
\text { - A provided the details on ... but B did not. } \\
\text { - A spoke about the advantages / disadvantages of ... but B did } \\
\text { not. }\end{array}$ & $\begin{array}{l}\text { Compre- } \\
\text { hension, } \\
\text { analysis }\end{array}$ \\
\hline $\begin{array}{l}\text { Evaluation } \\
\text { in general }\end{array}$ & $\begin{array}{l}\text { 1. I like A's recording because } \\
\text { - his / her pronunciation is accurate ... } \\
\text { - the content is substantial ... } \\
\text { - the tone is emotive ... }\end{array}$ & $\begin{array}{l}\text { Analysis, } \\
\text { evaluation }\end{array}$ \\
\hline $\begin{array}{l}\text { Specific } \\
\text { critique }\end{array}$ & $\begin{array}{l}\text { 1. I feel/think that } \\
\text { - A used too many English terms ... } \\
\text { - A used this idiom incorrectly ... } \\
\text { - A paused too often in his / her reading ... } \\
\text { - A's recording can hardly be heard ... }\end{array}$ & Analysis \\
\hline Suggestion & $\begin{array}{l}\text { 1. I feel that } \\
\text { - A should have more confidence in him/herself, s/ he should } \\
\text { use longer sentences and use fewer English terms ... } \\
\text { - A should work on his / her intonation ... }\end{array}$ & $\begin{array}{l}\text { Appli- } \\
\text { cation, } \\
\text { analysis }\end{array}$ \\
\hline
\end{tabular}

Table 4: Sentence openings that scaffold students in their self-assessment using different metacognitive strategies (English translation)

\begin{tabular}{|c|c|c|}
\hline $\begin{array}{l}\text { Types of } \\
\text { comment }\end{array}$ & Sentence openings & $\begin{array}{l}\text { Types of meta- } \\
\text { cognitive strategy }\end{array}$ \\
\hline Self-assessment & $\begin{array}{l}\text { 1. I'm satisfied with my recording because ... } \\
\text { 2. I have made improvements because ... }\end{array}$ & $\begin{array}{l}\text { Evaluating, } \\
\text { monitoring }\end{array}$ \\
\hline $\begin{array}{l}\text { Self-assessment } \\
\text { through } \\
\text { comparison }\end{array}$ & $\begin{array}{l}\text { 1. Compared with my friend } \mathrm{A} \text {, my content is ... } \\
\text { 2. Compared with my previous recordings, this time I ... }\end{array}$ & $\begin{array}{l}\text { Evaluating, } \\
\text { monitoring }\end{array}$ \\
\hline $\begin{array}{l}\text { Planning for } \\
\text { improvement }\end{array}$ & $\begin{array}{l}\text { 1. My targets for the next recording are ... } \\
\text { 2. In the next recording, I'll try to ... } \\
\text { 3. In my next practice, I want to work on (some specific } \\
\text { areas) ... }\end{array}$ & Planning \\
\hline $\begin{array}{l}\text { Overall } \\
\text { evaluation of } \\
\text { learning } \\
\text { experience }\end{array}$ & $\begin{array}{l}\text { 1. After listening to my friends' recordings, my greatest } \\
\text { takeaway is ... } \\
\text { 2. After reading the comments given by my friends, my } \\
\text { greatest takeaway is ... } \\
\text { 3. In this cycle of practice, I learnt ... }\end{array}$ & $\begin{array}{l}\text { Evaluating, } \\
\text { monitoring }\end{array}$ \\
\hline
\end{tabular}


The pre-test, post-test, and all the oral performances were graded by three Chinese language teachers who had been appointed examiners for the GCE ' $\mathrm{O}$ ' Level oral examinations by the Ministry of Education and were familiar with the requirements of the national examination. The teachers graded the recordings independently and the students' identities were not revealed to these teachers.

\section{Audioblogs}

The audioblog served three main functions. Firstly, the audioblog platform enabled students to upload and share their oral performances with their peers (Figure 1). Secondly, the blog posts captured student's self-reflection. Through posting to their individual blogs, students reflected upon their completed speaking tasks and shared these reflections with their peers. Third, the comment feature of blogs enabled the students to exchange comments with their peers after listening to the peers' speaking performances. Comments provided by peers, which helped the students develop greater awareness of their own speaking performance, could also be included in their personal reflections.

The domain www.audioblogging.net was specially set up for this study so that the students could remember the website easily. Movabletype.org, an open source blogging platform, was used because it has a user friendly interface that was attractive to the youths and it includes essential functions like commenting.

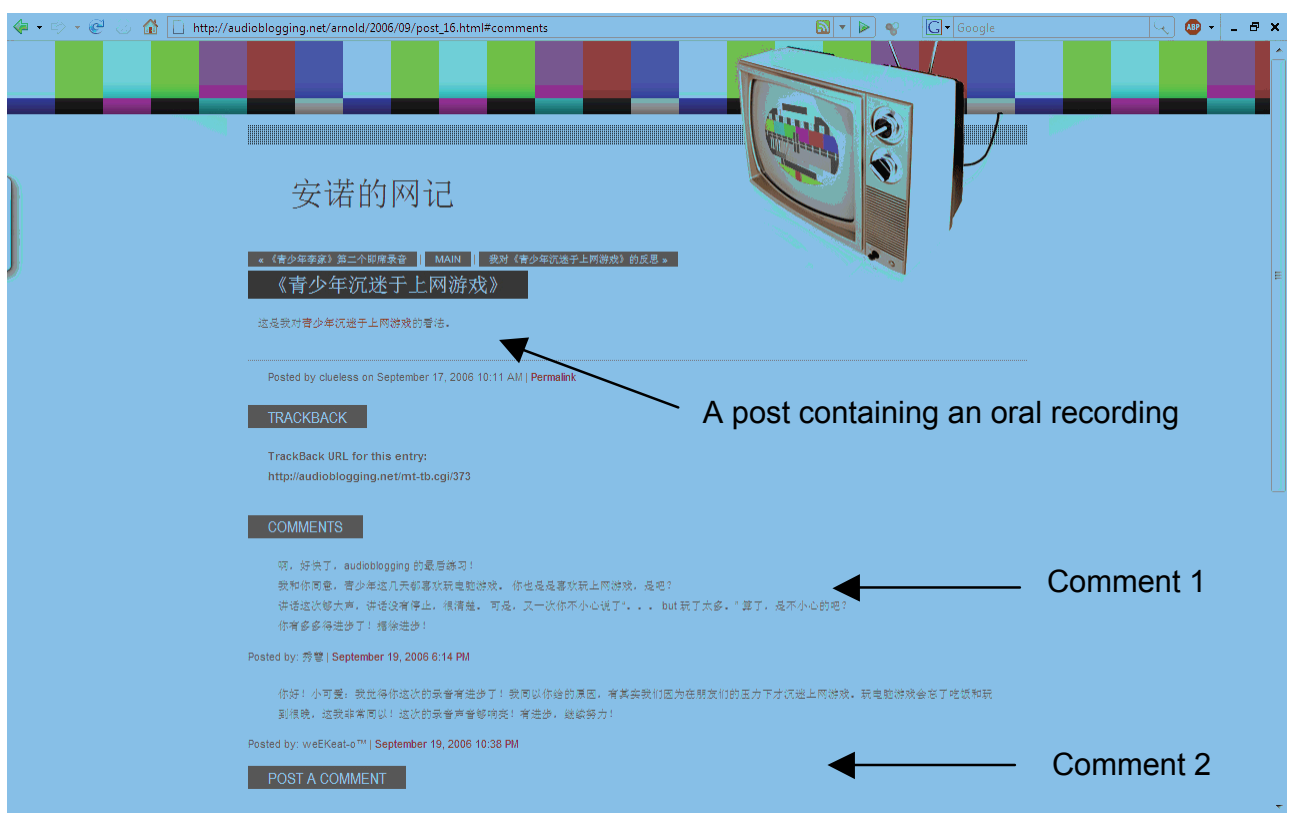

Figure 1: Screen capture of a student's audioblog

\section{Results}

Guided by the research questions, our investigation focused on two areas: the effect of the intervention on students' Chinese speaking skills, and the kinds of metacognitive behaviours displayed by the students in their self assessment. 


\section{Effects on students' Chinese speaking skills}

To answer the first research question on the effectiveness of the intervention in improving students' Chinese speaking skill, we examined the average mean scores awarded by the three teachers for the pre- and post-test of the seven students (Figure 2). Pseudonyms are used for confidentiality reasons. The maximum score for the test was 30 points, which include 15 points for Content and 15 points for Expression. Standardised Cronbach's alpha can be used as a measure of inter-rater reliability for scoring involving multiple judges (Stemler, 2004). In this study, the standardised Cronbach's alpha coefficients for inter-rater reliability were .88 for the pre-test and .79 for the post-test. A coefficient greater than .70 is considered acceptable (Stemler, 2004).

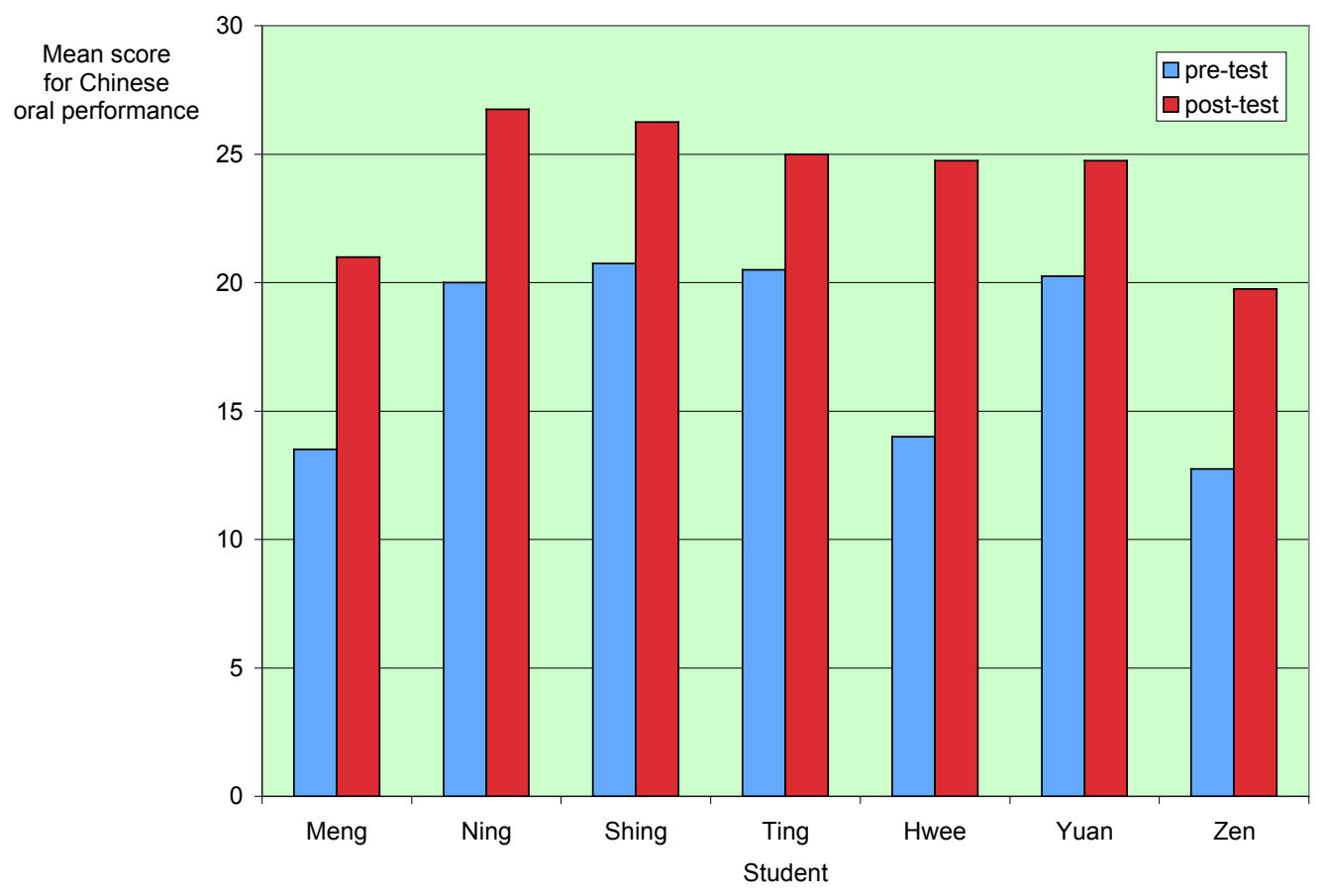

Figure 2: Mean scores of pre- and post-oral performances

Visual inspection of the mean scores showed that the students seemed to perform better in the post-test compared to the pre-test. Since the sample size was small, the pre- and post-test mean scores were compared using the non-parametric Wilcoxon test. Taking $\mathrm{W}$ as the sum of the signed ranks, $\mathrm{W}=-28$ for $n=7$. Using a two-tail test, it is significant at $\mathrm{p}=.02$ level. The mean score for the post-test oral performance is significantly higher than the pre-test mean score. This result suggests that the there was an improvement in the students' Chinese language speaking skill after the intervention.

\section{Students' metacognitive behaviours}

To answer the second research question, on students' metacognitive behaviours in their self assessment, content analysis (Neuendorf, 2002) was carried out. The data needed were captured as entries in the individual audioblogs. The categories used for 
coding metacognitive strategies were based on the metacognitive framework proposed by Goh and Zhang (2001): planning, monitoring and evaluating. The categories used to analyse the metacognitive knowledge used by the students were based on the classification of metacognitive knowledge by Wenden (1998): Task knowledge, person knowledge and strategy knowledge. In the students' self assessment, task knowledge was shown in comments that focused on the demands of the learning task or assessment on one's performance. Person knowledge manifested as comments on how one's learning style, circumstances or motivation could have affected the performance. Strategic knowledge was shown in comments that suggested how one can improve in future performances. These were 32 pieces of self assessment posted in the audioblogs of the seven students. The unit of analysis was a thematic unit that contains an idea. Choosing a thematic unit as the unit of analysis was appropriate and meaningful compared to a syntactic unit that is based on linguistic feature, because a single sentence could contain two or more ideas.

There were 175 instances of metacognitive behaviour identified. The distribution of the metacognitive strategy is summarised in Table 5.

Table 5: Metacognitive strategies and knowledge exhibited in students' self-assessment

\begin{tabular}{|l|l|c|c|}
\hline $\begin{array}{c}\text { Metacognitive } \\
\text { strategy }\end{array}$ & \multicolumn{1}{c|}{ Examples (English translation) } & $\begin{array}{c}\text { Number of } \\
\text { occurrences }\end{array}$ & Percentage \\
\hline Monitoring & $\begin{array}{l}\text { I have fewer pauses in this oral recording, but } \\
\text { there are still instances of stammering. } \\
\text { After listening to my peer's recording, I realise } \\
\text { that it is important to speak naturally. }\end{array}$ & 105 & $60.0 \%$ \\
\hline Planning & $\begin{array}{l}\text { In my next recording, I will increase my pace } \\
\text { and use a more emotive tone. } \\
\text { I need to reduce the number of pauses in the } \\
\text { next oral recording. }\end{array}$ & 37 & $21.3 \%$ \\
\hline Evaluating & $\begin{array}{l}\text { I am satisfied with my performance because I } \\
\text { could cite a few examples within a short time. } \\
\text { I feel that I have made an improvement } \\
\text { compared to my last recording. }\end{array}$ & 33 & $18.9 \%$ \\
\hline
\end{tabular}

The result showed that the students invested a larger amount of effort on monitoring how various factors could affect their oral performance. In contrast, a smaller amount of effort was devoted to evaluating speaking performance on the whole and planning for the next recording.

In terms of sequencing of the three strategies, among the 32 pieces of self-assessment, $31(96.9 \%)$ of these began by employing the evaluating strategy. This was always followed by the use of a monitoring strategy in all the cases. There was one reflection that began with the monitoring of the oral performance. In this reflection, the evaluation of the speaking task began midway through the reflection. Students used a planning strategy in 26 out of 32 self-assessment posts. In all these cases, the monitoring strategy always preceded the use of the planning strategy. Four of the six pieces of self assessment that did not demonstrate the planning strategy occurred in the last cycle of practice. It is possible that since it was the last cycle of practice, the students could have decided to leave out planning for the next speaking task in their reflection. 
In terms of the type of metacognitive knowledge that was used in the self assessment, task knowledge was most frequently exhibited (See Table 6). Students did not use person knowledge and strategy knowledge frequently.

Table 6: Metacognitive knowledge used in students' self assessment

\begin{tabular}{|l|l|c|c|}
\hline $\begin{array}{l}\text { Metacognitive } \\
\text { knowledge }\end{array}$ & \multicolumn{1}{|c|}{ Examples } & $\begin{array}{c}\text { Number of } \\
\text { occurrences }\end{array}$ & Percentage \\
\hline $\begin{array}{l}\text { Task } \\
\text { knowledge }\end{array}$ & $\begin{array}{l}\text { I forgot to include the causes in my recording. } \\
\text { My performance is not bad because I have fewer } \\
\text { pauses. }\end{array}$ & 151 & $86.3 \%$ \\
\hline $\begin{array}{l}\text { Person } \\
\text { knowledge }\end{array}$ & $\begin{array}{l}\text { I think I am too used to speaking in a fast pace, it } \\
\text { has become my habit. } \\
\text { Maybe I was too nervous during the recording } \\
\text { because my grandma was asking me to run some } \\
\text { errands. }\end{array}$ & 10 & $5.7 \%$ \\
\hline $\begin{array}{l}\text { Strategy } \\
\text { knowledge }\end{array}$ & $\begin{array}{l}\text { In my next recording, I will use more idioms. } \\
\text { In future, I will speak further away from place } \\
\text { the microphone. }\end{array}$ & 14 & $8.0 \%$ \\
\hline
\end{tabular}

The frequency of metacognitive knowledge suggests that the students' reflections focused on the content and their expression during the performance of a speaking task, but not much attention was devoted to the use of person knowledge and strategy knowledge in their self assessment.

To better understand the use of person knowledge and strategy knowledge during self appraisal, we analysed students' use of person knowledge and strategy knowledge across three metacognitive strategies. The distribution of the type of metacognitive knowledge used when students apply a metacognitive strategy is shown in Table 7 . It seems that person knowledge is used more often than strategy knowledge in monitoring strategy, and the reverse is true for planning strategy. The students rarely used person knowledge and strategy knowledge in their evaluation strategy.

Table 7: Metacognitive strategies and the corresponding metacognitive knowledge used in students' self appraisals

\begin{tabular}{|l|l|c|c|}
\hline $\begin{array}{c}\text { Metacognitive } \\
\text { strategy }\end{array}$ & \multicolumn{1}{|c|}{$\begin{array}{c}\text { Metacognitive } \\
\text { knowledge }\end{array}$} & $\begin{array}{c}\text { Number of } \\
\text { occurrences }\end{array}$ & Percentage \\
\hline \multirow{4}{*}{ Monitoring } & Person knowledge & 7 & $4.0 \%$ \\
\cline { 2 - 4 } & Task knowledge & 94 & $53.7 \%$ \\
\cline { 2 - 4 } & Strategy knowledge & 4 & $2.3 \%$ \\
\hline \multirow{4}{*}{ Planning } & Person knowledge & 1 & $0.6 \%$ \\
\cline { 2 - 4 } & Task knowledge & 27 & $15.4 \%$ \\
\cline { 2 - 4 } & Strategy knowledge & 9 & $5.1 \%$ \\
\hline \multirow{3}{*}{ Evaluating } & Person knowledge & 3 & $1.1 \%$ \\
\cline { 2 - 4 } & Task knowledge & 1 & $17.1 \%$ \\
\cline { 2 - 4 } & Strategy knowledge & 175 & $10.6 \%$ \\
\hline
\end{tabular}

We also examined the students' metacognitive behaviours when providing feedback to their peers. There were 27 comments made by these 7 participants. Task knowledge was most frequently used $(93.3 \%)$. Person knowledge $(5.9 \%)$ and strategy knowledge $(0.7 \%)$ were much lower in frequencies. Table 8 summarises these findings. 
Table 8: Frequencies and \% of times students made use of different areas of metacognitive knowledge when providing comments to peers

\begin{tabular}{|l|c|c|c|c|}
\hline \multicolumn{1}{|c|}{ Student } & $\begin{array}{c}\text { Person } \\
\text { knowledge }\end{array}$ & $\begin{array}{c}\text { Task } \\
\text { knowledge }\end{array}$ & $\begin{array}{c}\text { Strategy } \\
\text { knowledge }\end{array}$ & $\begin{array}{c}\text { Total } \\
\text { frequencies }\end{array}$ \\
\hline Meng & $1(4.8 \%)$ & $20(95.2 \%)$ & $0(0.0 \%)$ & 21 \\
\hline Ning & $3(33.3 \%)$ & $6(66.7 \%)$ & $0(0.0 \%)$ & 9 \\
\hline Shing & $0(0.0 \%)$ & $11(100.0 \%)$ & $0(0.0 \%)$ & 11 \\
\hline Ting & $0(0.0 \%)$ & $4(100.0 \%)$ & $0(0.0 \%)$ & 4 \\
\hline Hwee & $2(6.9 \%)$ & $27(93.1 \%)$ & $0(0.0 \%)$ & 29 \\
\hline Yuan & $0(0.0 \%)$ & $26(96.3 \%)$ & $1(3.7 \%)$ & 27 \\
\hline Zen & $2(5.9 \%)$ & $32(94.1 \%)$ & $0(0.0 \%)$ & 34 \\
\hline Total & $8(5.9 \%)$ & $126(93.3 \%)$ & $1(0.7 \%)$ & 135 \\
\hline
\end{tabular}

Similar to the metacognitive behaviours in self-assessment, the results showed that the students used their task knowledge most frequently when they provided comments to their peers. On the few occasions when person knowledge was used, the students took note of their peers as language learners with individual characteristics and provided comments. The use of strategy to critique their peers' speaking task appeared to have eluded the students except in one occasion.

\section{Discussion}

There is a significant improvement in students' pre- to post- Chinese oral performance; this resonates with the positive finding by Shih (2010) that the use of videoblogs could improve students' speaking skills. Barring the limitations of small sample size and the case study design, it provides an optimistic indication of the effectiveness of using audioblogging coupled with metacognitive scaffolding in improving students' Chinese speaking skills. It also echoes positive findings from research in the western world languages (e.g., Nakatani, 2005) on the benefits of incorporating metacognitive strategies.

The content analysis of students' self-assessment shows that they devoted greater attention to monitoring strategy compared to planning and evaluating strategy. A possible explanation is that there are more ways and aspects for monitoring one's performance, for example, by comparing performance with other students or commenting on various aspects of the oral performance like pace, fluency and use of vocabulary. A more detailed analysis revealed that the students adopted a systematic approach to self assessment. Most students' self assessment contained all three metacognitive strategies when they reflected on their speaking task. Although the scaffolds provided opportunities for different approaches to the self-assessment, a prominent pattern emerged in almost all the reflection notes: evaluating $\rightarrow$ monitoring $\rightarrow$ planning. In a few cases, some students added an additional evaluating step at the end, that is, evaluating $\rightarrow$ monitoring $\rightarrow$ planning $\rightarrow$ evaluating.

Among the three types of metacognitive knowledge, task knowledge served as the basis for the students' activities in the audioblogs. More than $86 \%$ of the occurrences in students' self assessment made use of task knowledge. Likewise, nearly $92 \%$ of the occurrences in students' peer critique made use of their task knowledge on the speaking task. This finding coheres with Zhang and Goh's (2006) finding that while Grade 9 Singaporean students were generally aware of the usefulness of listening and speaking strategies, their perceived use of these strategies was much less frequent. In 
our intervention, the term metacognition and its meaning were not made known to the students and the scaffolds provided to them were not labelled as metacognitive strategy or metacognitive knowledge. The fact that the students had focused very much on task knowledge showed their task-oriented disposition. The students might have a parochial view that merely focusing on the task components could help to improve one's speaking skills. They may not realise how other factors (e.g. learner's characteristics, application of learning strategies) could contribute to and affect their oral performances.

The findings also show that the students had the tendency to use person knowledge more often during monitoring of their past speaking tasks and they used strategy knowledge more often during their planning for their future speaking tasks. This imbalance in the application of metacognitive knowledge suggests that the students had not acknowledged the importance of how their individual characteristics can influence their future learning events and how learning strategies can be adapted and applied to suit their different personalities. We observed in the students' self assessment how their habits, such as the tendency to use "Singlish" (a colloquial variety of language used by Singaporeans), had affected some of their oral performances. It would probably be more effective if students were able to turn inwards to review their person knowledge and adapt their strategy knowledge accordingly each time they reviewed the past speaking task and planned for the future task. The finding that the students were not drawing as much on person knowledge and strategy knowledge also suggest that there is a need to raise their awareness and improve their abilities to draw upon these resources when learning to speak Chinese language. Of course, person knowledge and strategy knowledge cannot work in isolation without task knowledge. It is important to highlight to students the importance of synergising all three types of metacognitive knowledge so that their overall level of metacognitive awareness can be enhanced.

\section{Conclusions}

This study set out to examine a metacognitive approach to the learning of Chinese language speaking that made use of audioblogs as the ICT tool to facilitate language learning tasks. Using a Wilcoxon test, we found a significant improvement in the mean scores of pre- to post- students' oral performance, which is a positive indication of the benefits of this approach.

The scaffolding questions play an important role in scaffolding students' reflection and self-assessment. The students adopted a systematic approach in their reflection: evaluating $\rightarrow$ monitoring $\rightarrow$ planning, with greater amount of attention devoted to the monitoring strategy. A disproportionate distribution of metacognitive knowledge usage was found in students' self assessment. Task knowledge was the predominant metacognitive knowledge used by students; person knowledge and strategy knowledge were neglected by the students. Teachers who are keen to implement a similar instructional approach could develop strategies to focus the students' attention on the latter two types of metacognitive knowledge. These can possibly lead to an improvement in all three types of metacognitive knowledge.

The approach used in this study involved the use of audioblogs as the technological platform. The provision of disk space and the availability of bandwidth for the server are important considerations as voice recordings are relatively big in file size. As blogging technologies are still emerging, readers who are interested could explore 
newer audioblogging services, such as www.podbean.com, which include new features such as analysis tools, integration to other social software, and mobile access; web-based recording services, such as www.vocaroo.com, can also be explored for teachers who faced storage space constraints. Nevertheless, the introduction of these technologies into an oral speaking classroom can possibly tap on some experiences that we have shared in this paper.

\section{References}

Bartlett-Bragg, A. (2003). Blogging to learn. The Knowledge Tree. [viewed 16 March 2010 at http: / / knowledgetree.flexiblelearning.net.au/edition04/pdf/Blogging_to_Learn.pdf, verified 12 Dec 2010 at http:/ / hdl.handle.net/10453/6368 (PDF, 4.3 MB)].

Bloom, B. S. (Ed.). (1956). Taxonomy of educational objectives. Book 1: Cognitive domain. New York: Longman.

Bygate, M. (2001). Effects of task repetition on the structure and control of oral language. In M. Bygate, P. Skehan \& M. Swain (Eds.), Researching pedagogic tasks: Second language learning, teaching and testing (pp. 23-48). Harlow: Pearson Education Limited.

Davis, A. \& McGrail, E. (2009). Proof-revising with podcasting: Keeping readers in mind as students listen to and rethink their writing. The Reading Teacher, 62(6), 522-529.

Flavell, J. H. (1979). Metacognition and cognitive monitoring: A new area of cognitivedevelopment inquiry. American Psychologist, 34(10), 906-911.

Goh, C. C. M. \& Zhang, D. (2001). A metacognitive framework for reflective journals. In A. S. C. Chang \& C. C. M. Goh (Eds.), Teachers' handbook on teaching generic thinking skills (pp. 8-21). Singapore: Prentice Hall.

Gounari, P. (2009). Rethinking critical literacy in the new information age. Critical Inquiry in Language Studies, 6(3), 148-175.

Helmond, A. (2008). How many blogs are there? Is someone still counting? The Blog Herald, 11 February. [viewed 16 Mar 2010, verified 12 Dec 2010] http:/ / www.blogherald.com/2008/ 02/11/ how-many-blogs-are-there-is-someone-still-counting/

Hsu, H.Y., Wang, S.K. \& Comac, L. (2008). Using audioblogs to assist English-language learning: An investigation into student perception. Computer Assisted Language Learning, 21(2), 181-198.

Kaderavek, J. N., Gillam, R. B., Ukrainetz, T. A., Justice, L. M. \& Eisenberg, S. N. (2004). Schoolage children's self-assessment of oral narrative production. Communication Disorders Quarterly, 26(1), 37-48.

Kern. R. \& Warschauer, M. (2000). Theory and practice of network-based language teaching. In M. Warschauer \& R. Kern (Eds.), Network-based language teaching: Concepts and practice. Cambridge, England: Cambridge University Press.

Leahey, T. \& Harris, R. (1997). Learning and cognition. New Jersey: Prentice Hall.

Ladyshewsky, R. K. \& Gardner, P. (2008). Peer assisted learning and blogging: A strategy to promote reflective practice during clinical fieldwork. Australasian Journal of Educational Technology, 24(3), 241-257. http:/ / www.ascilite.org.au/ ajet/ ajet24/ladyshewsky.html

Lou, S.-J., Wu, S.-C., Shih, R.-C. \& Tseng, K.-H. (2010). Adoption of blogging by a Chinese language composition class in a vocational high school in Taiwan. Australasian Journal of Educational Technology, 26(6), 898-916. http: / / www.ascilite.org.au/ajet/ajet26/lou.html

Nakatani, Y. (2005). The effects of awareness-raising training on oral communication strategy use. The Modern Language Journal, 89(1), 76-91.

Neuendorf, K. A. (2002). The content analysis guidebook. Thousand Oaks, CA: Sage Publications. 
Paolillo, J. C. (2001). Language variation on Internet Relay Chat: A social network approach. Journal of Sociolinguistics, 5(2), 180-213.

Paris, S.G., \& Winograd, P. (1990). How metacognition can promote academic learning and instruction. In B. F. Jones \& L. Idol (Eds.), Dimensions of thinking and cognitive instruction (pp. 15-51). Hillsdale, New Jersey: Lawrence Erlbaum Associates.

Ray, J. (2006). Blogosphere: The educational use of blogs (aka edublogs). Kappa Delta Pi Record, 42(4), 175-177.

Rosell-Aguilar, F. (2005). Task design for audiographic conferencing: Promoting beginner oral interaction in distance language learning. Computer Assisted Language Learning, 18(5), 417-442.

Tekinarslan, E. (2008). Blogs: A qualitative investigation into an instructor and undergraduate students' experiences. Australasian Journal of Educational Technology, 24(4), 402-412. http: / / www.ascilite.org.au/ajet/ajet24/tekinarslan.html

Segerstad, Y. H. A. \& Ljungstrand, P. (2002). Instant messaging with WebWho. International Journal of Human-Computer Studies, 56(1), 147-172.

Shih, R.-C. (2010). Blended learning using video-based blogs: Public speaking for English as a second language students. Australasian Journal of Educational Technology, 26(6), 883-897. http: / / www.ascilite.org.au/ajet/ajet26/shih.html

Stake, R. (2005). Qualitative case studies. In N. Denzin \& Y. Lincoln (Eds.), The Sage handbook of qualitative research (3rd ed., pp. 443-466). Thousand Oaks, CA: Sage.

Stemler, S. E. (2004). A comparison of consensus, consistency, and measurement approaches to estimating interrater reliability. Practical Assessment, Research E Evaluation, 9(4). [viewed 16 March 2010] http: / / PAREonline.net/getvn.asp?v=9\&n=4

Sun, Y.C. (2010). Extensive writing in foreign language classrooms: a blogging approach. Innovations in Education and Teaching International, 47(3), 327-339.

Tse, S. K., Yuen, A. H. K., Loh, E. K. Y., Lam, J. W. I. \& Ng, R. H. W. (2010). The impact of blogging on Hong Kong primary school students' bilingual reading literacy. Australasian Journal of Educational Technology, 26(2), 164-179. http: / / www.ascilite.org.au/ajet/ajet26/tse.html

Volle, L. M. (2005). Analyzing oral skills in voice e-mail and online interviews. Language Learning E Technology, 9(3), 146-163. http:/ /llt.msu.edu/vol9num3/pdf/volle.pdf

Wang, Y. (2004). Supporting synchronous distance language learning with desktop videoconferencing. Language Learning $\mathcal{E}$ Technology, 8(3), 90-121. http: / / llt.msu.edu/vol8num3/pdf/wang.pdf

Wenden, A. L. (1998). Metacognitive knowledge and language learning. Applied Linguistics, 19(4), 515-537.

Yildiz, S. \& Bichelmeyer. B. A. (2003). Exploring electronic forum participation and interaction by EFL speakers in two web-based graduate-level courses. Distance Education, 24(2), 175-193.

Young, S. S. C. (2003). Integrating ICT into second language education in a vocational high school. Journal of Computer Assisted Learning, 19(4), 447-461.

Zhang, D. \& Goh, C. C. M. (2006). Strategy knowledge and perceived strategy use: Singaporean students' awareness of listening and speaking strategies. Language Awareness, 15(3), 199-219.

Yuh-Huann Tan, Educational Technology Division, Ministry of Education, Singapore. Email: yh2.com@gmail.com

Seng-Chee Tan (contact author), Learning Sciences and Technologies Academic Group, National Institute of Education, Nanyang Technological University. Email: sengchee.tan@nie.edu.sg 